\title{
Destroyed Windbreaks as One of The Main Causes of Agricultural Production Decrease in Georgia
}

\author{
Tamaz Patarkalashvili* \\ Technical University of Georgia, Center Studying Productive Forces and Natural Resources of Georgia, Georgia
}

*Corresponding author: Tamaz Patarkalashvili, Technical University of Georgia, Center Studying Productive Forces and Natural Resources of Georgia, Georgia.
Received Date: May 07, 2019

Published Date: May 22, 2019

\begin{abstract}
Windbreaks have very important economic, social and environmental value for sustainable development of the country. They increase crop and fruit quality and yield in sheltered areas by providing lower temperatures, increasing relative humidity and retaining soil moisture, reducing damage of soil erosion due to strong winds. The first windbreaks have been planted in Georgia in the early 1960s. Since that time they were developed in all agricultural lands in East and West parts of the country and played their positive role in increasing yields of different kind of crops (wheat, rye, corn, barley etc.), especially in East Georgia, as well as in West Georgia-tea and citrus yields (mandarins, oranges, lemons feijoas). In the Soviet period windbreaks always maintained well. This situation continued until 1991 when the Soviet Union broke up and the period of full chaos began. In process of natural gas and electricity deficit the local population logged and destroyed better part of nearby forests and windbreaks for firewood and cooking. These and other questions regarding windbreaks importance and need of their reconstruction are discussed in the article.
\end{abstract}

Keywords: Windbreak; Crop; Grass; Pasture; Agriculture; Yield; Sustainability

\section{Introduction}

Windbreaks have long been recognized for protecting soils, crops and livestock. The main positive influence of windbreaks on adjoin agricultural lands and yield increase consists in the fact that they are mechanical obstacle to wind current and significantly diminish its speed and turbulence. This fact influences on microclimate of lower part of the atmosphere near the earth of about 2-3m., namely, microclimate of soil formation, snow allocation on soil, hydrological process, underground water conditions etc. So, on agricultural land defended by windbreaks are created favorable conditions for growing plants to increase annual yield. They influence evaporation, transpiration, wind erosion, snow drifting and crop yields. Windbreaks are major component of successful agricultural systems throughout the world [1]. Usually they are consisting of trees and shrubs. Throughout the history they have been used to protect homes, crops and livestock, diminish wind erosion and blowing snow, provide habitat for wildlife and enhance the agricultural yields $[2,3]$.

By some sauce's windbreaks have their origins in the mid1400 s when the Scottish Parliament urged the planting of tree belts to protect agricultural production [4]. From that time shelterbelts have been used extensively throughout the world [5-7]. Besides crops field shelterbelts increase yield of forage crops. The increases are due to reduction of wind erosion, improved microclimate, snow retention and reduced crop damage by strong winds [8]. Crops differ in their responsiveness to shelterbelts. From the field and forage crops tested, winter wheat, barley, rye, millet, alfalfa and hay (mixed grasses and legumes) appeared to be highly responsive to protection, while spring wheat, oats and corn, respond to a lesser degree $[9,10]$. Shelterbelt height and longevity, field width and shelterbelt orientation are major consideration in determine the effect of shelterbelts on crop yields. Precipitations have an effect on the percentage of yield increase too. Generally, percentage of yield is higher in drier regions and drier years [11].

An analysis of yield increase was summarized on worldwide study in 1986 at the First International Windbreak Conference and indicated significant yield increases for winter wheat (23\%), soybeans (15\%) and corn (12\%) [8]. While windbreaks have positive impact on crop yields, it declines on the agricultural lands closely adjacent to windbreaks. Competition between tree and crop roots for soil moisture and shading is likely the primary cause for yield reduction on lands adjacent to windbreaks [8]. The greatest yield increase occurs between 2 and 6 ha and then starts to decrease as 
wind speed increases. The zone of increased crop yield can be extended up to 13-25ha [10]. Frank reported that wheat yield increases on $22 \%$ and $19 \%$ for irrigated and non-irrigated sheltered fields respectively [11].

Environmental impact of windbreaks is observed in improved microclimate, soil formation, water regulation, snow retention, support of the wildlife habitat and biodiversity conservation, carbon sequestration and soil and air temperature moderation, reduction of carbon dioxide emissions to prevent global warming. Windbreaks provide nectar and pollen for bees. Many bird species use windbreaks for habitat. Apart from economic and environment benefits, windbreaks have social value that's reflected by the fact that windbreaks can be not only the source of wood and food, but aesthetic value as well.

\section{Results and Analysis}

In the Soviet period windbreaks began to plant since late 1930s and continued after WWII. In Russia first windbreaks were planted since 1696 by Peter the Great's order to defense steppes lands from dry winds. In 18-19 centuries up to 1917 have been planted 130 thousand-hectare windbreaks on more than 900 thousand hectares. In 1986 there were 1.8 million-hectare windbreaks. It must be underlined that first scientific approach for windbreaks significance was done by outstanding Russian scientist V.V. Dokuchaev in 1892 in his capital work, "Our steppes before and now" [12]. Besides Dokuchaev V.V. there were many well-known scientists in Russia like, Villiams V.R. [13], Khodorovich P. [14] and others.

In Georgia windbreaks began to plant from 1960s and they played positive role increasing yield of crops, tea, citrus and other plants. After breaking up of the Soviet Union the situation in the country deteriorated. In cold winter of 1991 Russia stopped submission of energetic resources (natural gas, petrol, electricity). In this process of political, socio-economic and energetic chaos nobody cared of windbreaks. Losing their temper population living in inhuman conditions began to cut nearby forests and windbreaks. The most damaged occurred windbreaks, being nearer to the settlements. As a result, about $80 \%$ of windbreaks have been logged and destroyed. The remained $20 \%$ is degraded and need reconstruction and rehabilitation.

\section{Short climate review of Georgia}

For better understanding the agricultural conditions of growth of different plant species which need windbreaks protection we are giving the major climatic characteristics of east and west parts of Georgia.

Georgia's climate is extremely diverse taking into account it's small territory. The great Caucasus Mountain Range has a very important role in moderating Georgia's climate and protect the country from penetration of cold air masses from the north. The lesser Caucasus Mountain range protects the region from dry and hot air masses from the south. Considerable part of western Georgia is characterized by humid subtropical climate with annual precipitation from 1,000 to $4000 \mathrm{~mm}$. The climate of western Georgia varies significantly with elevation.
The eastern Georgia has transitional climate from humid subtropical, near Likhi and Meskhety mountain range, to the continental, from Shida Qartli region. The east Georgia's climate is influenced by dry Caspian air masses from the east and humid Black Sea air masses from the west. The penetration of humid air masses from the Black Sea is often blocked by mountain ranges of Likhi and Meskhety which separate the eastern and western parts of the country. Annual precipitation in east part of Georgia is lesser than in west, from 400 to $1600 \mathrm{~mm}$. The better part of eastern Georgia has hot summers (especially in plains) and relatively cold winters. Wettest periods occur in spring and late autumn, while winter and summer months are the driest.

\section{Prehistory of windbreaks in Georgia}

Windbreaks history began in Georgia from 1960s. In west part of the country they were mainly used to protect tea bushes and citrus (mandarins, lemons. oranges, feijoas). By geographical terrain of west Georgia can only be explained the prevalence of different wind points and their strength (Table1). As we see from the table the strongest winds blow from west.

Table 1: Repeatability of different wind points in west Georgia regions.

\begin{tabular}{|c|c|c|c|c|c|c|c|c|c|}
\hline \multirow{2}{*}{ Region } & \multicolumn{10}{|c|}{ Wind Points } \\
\cline { 2 - 12 } & N & Ne & E & Se & S & Sw & W & Nw & W \\
\hline Poti & 3 & 10 & 35 & 5 & 8 & 17 & 15 & 7 & 70 \\
\hline Gali & 8 & 9 & 26 & 12 & 10 & 9 & 19 & 7 & 743 \\
\hline Zugdidi & 4 & 9 & 36 & 10 & 6 & 14 & 18 & 4 & 603 \\
\hline Samtredia & 1 & 2 & 46 & 4 & 2 & 3 & 39 & 5 & 519 \\
\hline Tsalenjikha & 11 & 18 & 6 & 12 & 5 & 23 & 7 & 18 & 97 \\
\hline Gegechkori & 7 & 5 & 28 & 6 & 5 & 5 & 32 & 12 & 144 \\
\hline Kutaisi & 9 & 13 & 21 & 10 & 3 & 5 & 29 & 10 & 424 \\
\hline Kharagauli & 0 & 5 & 31 & 33 & 3 & 1 & 12 & 16 & 780 \\
\hline Tkibuli & 9 & 35 & 12 & 2 & 5 & 32 & 4 & 1 & 250 \\
\hline
\end{tabular}

Source: Targamadze K., Farjanadze L. 1955. Windbreaks and their significance for Georgia. 176pp. (in Georgian).

Windbreaks have significant positive influence on growth of tea bush branches. According to research made by V.Mgaloblishvili in Tslukidze Savkhoz (Soviet farm), in 1943, due to dust storms, tea leave yields decreased considerably. It can be explained by falling and striking of dust particles on soft leaves of tea bushes that mechanically damage them (Table 2). In the places without windbreaks the third part of yield occur of third grade and remained $70-75 \%$ without any grade. From the places defended by windbreaks yield of tea leaves were $56 \%$ more, than on places without windbreaks.Another experiment was made on 80 tea bushes from which 40 were defended by windbreaks and 40 without (Table 3 ). From 40 tea bushes defended with windbreaks yield was $2.5 \mathrm{~kg}$. more than from undefended ones. If we consider yield of tea leaves from undefended places 100 per cent, the yield from defended places will be on $56.3 \%$ more. During the vegetation period from each bush defended from east winds the yield was on 63 grams more than from undefended. According to agricultural rules on one hectare must be planted 15 thousand bushes. So only by help of windbreaks we can increase tea leaves yield on 945kg. comparing undefended with windbreaks places. In addition of yield increase 
the leaves from windbreak defended places are softer and better by quality. Scientist of Moscow Subtropical Institute P. Vadachkoria made investigations about strong winds adverse influence on citrus. He found out that east, as well as west winds destroy mandarin, lemon, orange and faijoa not only in winter, but in vegetation period as well. According to his research on undefended parts of mandarin plantation from north-east winds adverse influence were lost about
$90 \%$ of mandarin leaves. Their branches and stems have also been damaged. But on opposite of wind blowing direction side leaves, as well as stems were damaged lesser. On wind blowing side were saved about $36 \%$ of mandarins and on opposite side of wind blowing-64\%. From defended side of plantation were picked from each tree in average 613 fruits and from undefended only 383.

Table 2: Average growth of 10 tea bushes defended by windbreaks and 10 without them, $\mathrm{mm}$.

\begin{tabular}{|c|c|c|c|c|c|c|c|c|c|c|c|c|}
\hline S. No. & Place & \multicolumn{4}{|c|}{ Bushes Numbers and Average Growth Of Branches } \\
\hline & & $\mathbf{1}$ & $\mathbf{2}$ & $\mathbf{3}$ & $\mathbf{4}$ & $\mathbf{5}$ & $\mathbf{6}$ & $\mathbf{7}$ & $\mathbf{8}$ & $\mathbf{9}$ & $\mathbf{1 0}$ & Total \\
\hline 1 & Place defended by windbreaks & 381 & 367 & 382 & 411 & 393 & 434 & 323 & 403 & 394 & 422 & 3910 \\
\hline 2 & Place without windbreaks & 293 & 280 & 284 & 273 & 285 & 307 & 293 & 295 & 221 & 306 & 2837 \\
\hline 3 & Difference of growth in mm. & 88 & 87 & 98 & 138 & 108 & 127 & 30 & 108 & 173 & 116 & 1073 \\
\hline
\end{tabular}

Source: Targamadze k., Parjanadze L. 1955. Windbreaks and their significance for Georgia. 176pp. (in Georgian).

Table 3: Tea leaves yield in grams.

\begin{tabular}{|c|c|c|c|c|c|c|}
\hline \multirow{2}{*}{ Month } & \multirow{2}{*}{$\begin{array}{l}\text { Frequency of } \\
\text { Winds }\end{array}$} & \multicolumn{2}{|c|}{ Wind Speed m/sec. } & \multicolumn{3}{|c|}{ Tea Leaves Yield in Grams } \\
\hline & & Middle & Maximal & Defended Bushes & Undefended Bushes & Increase \\
\hline May & 33 & 5.6 & 17 & 1400 & 850 & 550 \\
\hline June & 7 & 2.5 & 4 & 610 & 570 & 40 \\
\hline July & 20 & 6.4 & 17 & 1570 & 1020 & 550 \\
\hline August & 89 & 7 & 17 & 1600 & 900 & 700 \\
\hline September & 12 & 6.1 & 17 & 1250 & 830 & 420 \\
\hline October & 28 & 7.2 & 17 & 550 & 300 & 250 \\
\hline Total & 189 & - & - & 6980 & 4470 & 2510 \\
\hline
\end{tabular}

Source: Targamadze K., Parjanadze L. 1955. Windbreaks and their significance for Georgía. 176pp. (in Georgian).

Interesting research materials were received by K. Targamadze and L. Parjanadsze in 1949-1950 in Tsikhisdziri (Ajara) where very strong frosts took place in these years. The major part of mandarin plantations was saved in places defended by windbreaks. In average 400-500 mandarins were saved on each tree. The east point winds also have adverse influence on citrus in flowering period. In the places not defended by windbreaks due to strong winds many flowers fell down. Strong and hot winds detain fruit growth in summer and many of them are falling down.
Strong winds take away the most fruitful upper layer of soils of about several centimeters if they are not defended by windbreaks. In Table 4 are presented the results of research made by D. Samadashvili [15] about crop damage made by strong winds in 1946 in different region of Georgia (Table 4). As we see 24.1 thousand hectares from 54.1 thousand of crop lands were destroyed on $100 \%$ and partially some places were destroyed on 75\%-9.1 thousand and on $50 \%,-20.9$ thousand crops.

Table 4: Crop damage from strong winds in 1946 in efferent regions of Georgia.

\begin{tabular}{|c|c|c|c|c|c|}
\hline \multirow{2}{*}{ S.No. } & \multirow{2}{*}{ Region } & \multicolumn{3}{|c|}{ Crop Damage from Strong Winds in 1st Decade of April 1946, \% } & \multirow{2}{*}{ Total (Thousand Hectare) } \\
\hline & & $100 \%$ & $75 \%$ & $50 \%$ & \\
\hline 1 & Khashuri & 0.2 & - & 0.2 & 0.4 \\
\hline 2 & Kareli & 0,4 & - & 0.6 & 1 \\
\hline 3 & Gori & 1.2 & 1.1 & 0.9 & 3.2 \\
\hline 4 & Kaspi & 0.9 & 0.6 & 0.5 & 2 \\
\hline 5 & Mtskheta & 0.8 & 0.2 & 1.2 & 2.2 \\
\hline 6 & Tbilisi & 1.6 & - & - & 1.6 \\
\hline 7 & Gardabani & 0.7 & 0.2 & 0.4 & 1.3 \\
\hline 8 & Sagarejo & 1.5 & - & 6.3 & 7.8 \\
\hline 9 & Katsreti & 1.5 & - & 4.8 & 6.3 \\
\hline 10 & Signaghi & 4 & - & 6 & 10 \\
\hline 11 & Tsiteltskaro & 11.3 & 7 & - & 18 \\
\hline Total & 24.1 & 9.1 & 20.9 & 54.1 & \\
\hline
\end{tabular}

Source: Farjanadze L.1951. Windbreaks 96pp. (in Georgian). 


\section{Prospects of windbreaks rehabilitation and reconstruc- tion}

Georgia is one of the former Soviet republics now transmitting from command to market economy, a country with small economy and budget ability. Major part of scientific institutions has been abolished after breaking up of the Soviet Union. The remained have been diminished greatly, with small financial resources not enough to maintain scientific investigations, high level research and monitoring of processes taking place in the country and current world $[16,17]$. That's why the government couldn't find financial and scientific resources in last 28 years of independence to rehabilitate the destroyed windbreaks that's so important for increasing agricultural production and food security of the country.

Today Georgia is importing a considerable part of agricultural products from neighboring countries, instead of exporting itself, because the favorable edaphic and climatic conditions facilitate sufficient increase of agricultural production. In case of proper management and financial and scientific support Georgia can produce agricultural products enough to satisfy not only local demand but export to other countries. Last but not least reason in addition is the fact that local agricultural products are free of chemicals and are grown in environmentally clean conditions.

In 2017 Agrarian Committee of Parliament of Georgia initiated the draft law on windbreaks, but the process of discussion showed that it would be difficult to achieve consensus among concerned parties if there wouldn't be clear vision on regulation of responsibilities in management of windbreak $[18,19]$. So, Ministry of environment protection and agriculture (MERA) initiated for working out conception on sustainable management of windbreaks. This conception was prepared by support of "giz" (Deutsche Gesellschaft für Internationale Zusammenarbeit) in framework of the Global Environment Fund project "Sustainable management of soil resources on agricultural lands decreasing soil degradation and poverty". The project was also funded by Austrian Development Cooperation.

In the process of working on this conception were analyzed the existing law on windbreaks and institutional organization, arrangement of responsibilities among government bodies. On basis of research made by "giz" was prepared document that was considered by all concerning sides. It all resulted in preparing several models of windbreaks management with analysis of positive and negative possibilities of their implementations. Finally, was prepared the working conception on windbreaks management in Georgia.

After adoption of law on windbreaks (presumably in 2019), MERA must prepare by January 2020 the plan of windbreaks rehabilitation and reconstruction. Ministry of Economy and Sustainable Development must prepare the plan of windbreaks inventory by 30 November 2019. So, if everything will go according to the plan in 10-15 year, we'll have windbreaks high enough when they begin their positive influence on crops and other agricultural plants and the situation will improve [20].

\section{Conclusion}

Our research showed that about $80 \%$ of former windbreaks in Georgia are destroyed due to energy problems at the beginning of
1991 and following years. Other 20\% are also degraded and need reconstruction. Windbreaks or shelterbelts are barriers used to reduce wind speed. They defend agricultural lands from wind erosion that sometimes has catastrophic destructive results taking away the most fruitful upper layer of soil-humus. 28-year past from independence of the country and none of the governments in this period found time and finances to rehabilitate them. The country with favorable soil and climatic resources has to import major part of agricultural products from neighboring countries. Now the light at the end of the tunnel appeared. Last year the agricultural committee of the Parliament of Georgia initiate the draft law on windbreaks. Besides, with financial and scientific support of Germany and Austria was prepared the conception of sustainable management of windbreaks. Agricultural production and food security are one of the major pillars of any country. So, we hope that in 10-15 years our windbreaks will be reconstructed, and we'll be able to increase yield of agricultural production.

\section{Acknowledgement}

None.

\section{Conflict of interest}

No conflict of interest.

\section{References}

1. Lyles L, Tatarko J, Dickerson JD (1984) Windbreak Effects on Soil water and Wheat Yield. Transactions of the ASAE 27(1): 69-72.

2. Baker TP, MT Moroni, DS Mendham, R Smith, MA Hunt (2018) Impacts of windbreak shelter on crop and livestock production. Crop and Pasture Science 69(8): 785-796.

3. Cleugh HA (1998) Effects of windbreaks on airflow, microclimates and crop yields. Agroforestry Systems 41(1): 55-84.

4. Droze WH (1977) Trees, Prairies and People: A History of Tree Planting in the Plains States. USDA Forest Service and Texas Woman's University Press, Denton, TX, 313 pp.

5. Cleugh HA, Hughes DE (2002) Impact of shelter on crop microclimates: A synthesis of results from wind tunnel and field experiments. Australian Journal of Experimental Agriculture 42(6): 679-701.

6. Caborn JM (1971) The agronomic and biological significance of hedgerows. Outlook Agriculture 6: 279-284.

7. Grace J (1988) Plant response to wind. Agriculture, Ecosystems \& Environment 22(23): 71-88.

8. kort J (1988) Benefits of Windbreaks on Field and Forage Crops. Agriculture Ecosystems \& Environment 22(23): 165-190.

9. Bird PR (1998) Tree windbreaks and shelter benefits to pasture in temperate grazing systems. Agroforestry Systems 41(1): 35-54.

10. Stoeckeler JH (1962) Shelterbelt influence on Great Plains field environment and crops. USDA, FS, Prod res 62: 1-26.

11. Frank $A B$ (1976) Influence of windbreaks on crop performance and management in North Dakota. Sym Proc Shelterbelts on the Great Plains. Great Plains Agr Council 78: 41-48.

12. Dokuchaev VV (1953) Our Steppes Before and Now. In: selected works 2: 152 .

13. Villiams V (1949) General Farming. 138pp.

14. Khodorovich P (1951) Field Protecting afforestation.

15. Brandle JR, L Hodges, XH Zhou (2004) Windbreaks in North American Agricultural Systems. Agroforestry Systems 61(1-3): 65-78.

16. Targamadze K, Farjanadze L (1955) Windbreaks and their significance for Georgia. 176pp. 
17. Farjanadze L (1951) Windbreaks. 96 pp.

18. Targamadze K, Berozashvili A (1974) Windbreaks and Agricultural Yields. 87pp.
19. Vadachkoria G (1942) Report of research on tea and citrus.

20. Mgaloblishvili V (1943) Winds influence on citrus and windbreaks. 